\title{
Personality and Leadership Qualities among Student Leaders
}

\author{
Ming Sing Chai \\ Leonard Personality Centre of Excellence, Tunku Abdul Rahman University College, Kuala Lumpur, Malaysia
}

\section{Email address:}

chaims@acd.tarc.edu.my

\section{To cite this article:}

Ming Sing Chai. Personality and Leadership Qualities among Student Leaders. American Journal of Applied Psychology. Special Issue: Psychology of University Students. Vol. 4, No. 3-1, 2015, pp. 27-32. doi: 10.11648/j.ajap.s.2015040301.15

\begin{abstract}
This research focused on a group of student leaders who have been elected by their peers to hold various positions in societies and clubs in the university setting. It explored the leadership qualities that student leaders had and the influence of personality on those leadership qualities among student leaders. A total of 59 participants from a private university college in Malaysia were involved, with 33 males and 26 females. Leonard Personality Inventory (LPI) online was used to assess the personality dimensions. Participants were asked to do a self-rating on 10 leadership qualities listed in [17]. Findings showed that student leaders chosen by their peers had very high integrity. Multiple regression results showed Neutral personality dimension was the most significant predictor for the leadership quality of showing concern for others. Open personality dimension was a significant predictor for self-confidence. Similarly, Relational personality dimension was a significant predictor for both charisma and integrity. To a certain extent, personality of leaders influences the leadership qualities that they display readily and some leadership qualities such as charisma need to be further enhanced through leadership training.
\end{abstract}

Keywords: Personality, Leadership Qualities, Leadership Training, Student Leaders

\section{Introduction}

University is a training ground for future leaders. In the Malaysian tertiary education system, acquisition of leadership skills as one of the seven soft skills elements in human capital development among undergraduates is emphasized [1]. It is a requirement for each university to incorporate the training of student leadership as part of the program learning outcome expected from graduates as a result of their university education. Besides leadership development and training directly associated with the academic curriculum, many students' societies and clubs are formed in the campus setting to provide leadership opportunities for students to learn and practice their leadership skills as part of their extra-curricular activities. By the time students graduated from a program, they are expected to have mastered not only technical knowledge and skills but also soft skills especially leadership skills.

Previous study has showed that students were aware of the importance of leadership as they perceived leadership experience as important in the campus and even after college as indicated by a student survey on attitudes about student leadership [2]. Organizations and societies at large need good, competent and efficient leaders. Studies have shown that leadership can affect employees' work performance and their well-beings, influence job satisfaction and organizational commitment among employees [3 - 5]. Therefore, leadership skills will be important to the future career of students and these leadership skills can be formed and developed while students are still pursuing their undergraduate studies.

The importance of students leadership has been explored among nursing students [6 - 8], engineering students [9], students involved in youth ministry [10], and business administration department students [11]. Most of these researches explored the effectiveness of leadership and leadership behaviors among students in general. The researcher is of the opinion that it is also important to assess what student leaders already have in terms of leadership qualities and personality traits in order to further develop their leadership abilities with the incorporation of the awareness of their own personality, their strengths and weaknesses. Leadership is an art that has its own uniqueness [12]. Therefore, good leaders need to be able to make use of whatever they have such as characters, and leadership qualities according to the needs of their members and situations in order to give impact to other people's lives.

This research focuses on a group of student leaders who 
have been elected by their peers to hold various positions in societies and clubs in a private university college. The aims of this research are to explore the personality traits and leadership qualities of student leaders and to gain an understanding on the types of personality that can predict leadership qualities among student leaders. It hopes to provide insights regarding areas in which leadership qualities can be enhanced to help these emerging leaders get better prepared to lead in the future.

\subsection{Leadership Qualities}

Leaders are someone who can use interpersonal skills to influence attitudes, beliefs, feelings and behaviors of others. They lead and guide the performance of the group [13]. In the past, researches had been done to explore the characteristics that can help to differentiate effective from ineffective leaders [14 - 15]. A meta-analysis on the relationship between individual characteristics and effectiveness of leadership showed that there is a link between individual differences and leadership emergence or effectiveness [16].

From the perspective of leadership trait theory, it is assumed that personal qualities are contributors to effective leadership. It is believed that a successful and efficient leader has some physical and psychological characteristics that make him or her different from non-leader [17]. Different researches throughout the history have identified different leadership qualities that leaders possessed [14, 18]. Common leadership qualities that appear in most reviews as reported in Pierce and Newstrom [13] are self-confidence, adjustment, sociability, integrity, persistence, initiative, responsibility, and insight. Most of these qualities identified are based on researches done on leaders from the working world nested in the western culture. There is a lack of studies reporting students' leadership qualities in Malaysia which may differ from the other studies due to geographical, cultural, and situational differences. The present study seeks to explore the type of leadership qualities that student leaders have in the Malaysian context.

\subsection{Personality and Leadership Qualities}

Personality refers to consistent pattern of behaviors, thoughts and feelings that are unique to each individual, persists through time and different situations. It can be examined from various perspectives using different personality theories. Friedman and Schustack [19] outlined eight basic aspects of personality: Psychoanalytic, Neo-analytic, biological, behaviorist, cognitive, trait, humanistic and interactionist.

From the perspective of trait, personality is viewed as consistent pattern of behaviors that is stable and enduring. Since personality traits are relatively permanent, consistent and unique to a person's behavior [20], they can be measured by personality inventories [21]. Although personality traits are laid down at birth and influenced by genetic, they can also be formed by individual experiences during lifetime. These traits are adaptive entities. Some personality traits develop over time, they can be adapted and changed at the later periods of individuals' lives as they go through life experiences, learn new ways of adapting to the world. The pattern of traits for each individual is unique although they are common traits that can be used to categorize people using generalized characteristics [22].

From the review of literature, Curtis, Vries and Sheerin [6] suggested that certain personal traits such as openness, extroversion, motivation to manage, relationship qualities such as effective communication and being approachable can contribute to nursing leadership. Judge, Bono, Ilies, and Gerhardt [23] did a very comprehensive meta-analysis between five-factor model of personality and leadership using 222 correlations from 73 samples. They found that extraversion, conscientiousness and openness personality traits were significant predictors of leadership. Extraversion was the strongest and most consistent correlate of leadership across leader emergence and effectiveness, followed by conscientiousness and openness. Extraversion was consistently correlated to leadership covering different study settings and leadership criteria such as leader emergence and leadership effectiveness. In this study, a different personality inventory will be used to measure personality traits and it is hypothesized that personality dimensions will be able to predict leadership qualities among student leaders.

\section{Methods}

\subsection{Participants and Procedures}

Participants in this study were student leaders $(n=59)$ who held leadership positions for academic societies $(n=17)$ and non-academic societies $(n=42)$ in a private Malaysian university college. Of the total 59 participants, 33 were males and 26 were females. In terms of leadership positions held, 19 were presidents, 4 were vice presidents, 16 were secretaries, 4 were treasurers, and 16 were committee members. Each participant completed the Leonard Personality Inventory (LPI) online and completed the other research questionnaires administered by the researcher during a leadership camp.

\subsection{Instruments}

Leonard Personality Inventory (LPI) was developed by Leonard Yong after many years of research into personality traits among Malaysians [24]. This instrument was used to assess five personality dimensions of an individual: Openness, Analytical, Neutral, Relational and Decisive. It consists of 100 items with each item rated on a 5-point scale ( 1 =disagree strongly, $2=$ disagree a little, $3=$ neither agree nor disagree, $4=$ agree a little, 5=agree strongly). The LPI was available online at www.leonard.com.my. The reliability of LPI was measured using Alpha Cronbach reliability coefficients, ranging from 0.71 for Decisive to 0.80 for Openness [25].

Leadership qualities consist of a list of 10 qualities as outlined in Manning and Curtis [17]. Participants were asked 
to rate themselves on each of the ten leadership qualities that they have by circling a number from 1 (low) to 10 (high). The ten qualities were: 1) Vision - a sense of purpose and able to recognize what could and should be done. 2) Ability has the job knowledge and expertise to guide and make decision in order to achieve results. 3) Enthusiasm - personal commitment that motivates and persuades people to become interested in what the leader is trying to accomplish. 4) Stability - emotional stability and objectivity in relating with self and others in challenging situations. 5) Concern for others - show sincere interest and care for the welfare of others and followers. 6) Self-confidence - inner strength that comes from preparation and competence to overcome difficult tasks. 7) Persistence - has the drive and determination to persevere in difficult tasks in order to complete them. 8) Vitality - lively, full of strength and stamina. 9) Charisma - magnetic ability to generate interest in people and cause them to follow. 10) Integrity - honesty, strength of character, and courage to stand by your word that generates trust [17]. Reliability for this part of the instrument using the current research sample was high, 0.89 as measured by Cronbach's Alpha coefficient.

\section{Results}

\subsection{Leadership Qualities}

Means and standard deviations of leadership qualities were shown in Table 1 . The leadership quality with the highest score among student leaders was integrity $(\mathrm{M}=8.03, \mathrm{SD}=$ 1.52 ), followed by persistence, vision, concern for others, enthusiasm, ability, self-confidence, and vitality. Their mean scores were ranged between 7.00 and 7.90, which were considered average and some improvements on those leadership qualities were needed (Manning \& Curtis, 2007). The leadership quality with the lowest score was charisma (M $=6.76, \mathrm{SD}=1.86$ ). Much work may be needed to improve the leadership quality of charisma among student leaders. Overall, the leadership qualities demonstrated by student leaders were average. No significant difference in leadership qualities was found among student leaders according to the leadership position held and gender.

Table 1. Leadership Qualities among Student Leaders.

\begin{tabular}{llll}
\hline Leadership Qualities & Mean & SD & N \\
\hline Integrity & 8.03 & 1.52 & 59 \\
Persistence & 7.71 & 1.52 & 59 \\
Vision & 7.61 & 1.53 & 59 \\
Concern for others & 7.49 & 1.38 & 59 \\
Enthusiasm & 7.46 & 1.85 & 59 \\
Ability & 7.42 & 1.49 & 59 \\
Stability & 7.41 & 1.69 & 59 \\
Self-confidence & 7.27 & 1.95 & 59 \\
Vitality & 7.24 & 1.55 & 59 \\
Charisma & 6.76 & 1.86 & 59 \\
Overall & 74.41 & 11.81 & 59 \\
\hline
\end{tabular}

SD: Standard Deviation, N: Number of Participants

\subsection{Personality and Leadership Qualities}

Table 2. Multiple Regression Predicting Leadership Qualities according to Personality.

\begin{tabular}{|c|c|c|c|c|c|c|c|c|c|c|c|c|}
\hline \multirow[t]{2}{*}{ Personality } & \multicolumn{2}{|c|}{ Vision } & \multicolumn{2}{|c|}{ Ability } & \multicolumn{2}{|c|}{ Enthusiasm } & \multicolumn{2}{|c|}{ Stability } & \multicolumn{2}{|c|}{ Concern for Others } & \multicolumn{2}{|c|}{ Self-Confidence } \\
\hline & $r$ & $\beta$ & $\mathrm{r}$ & $\beta$ & $\mathrm{r}$ & $\beta$ & $\mathrm{r}$ & $\beta$ & $\mathrm{r}$ & $\beta$ & $\mathrm{r}$ & $\beta$ \\
\hline Openness & .241 & .044 & .232 & .008 & .252 & .024 & .226 & .041 & .067 & -.028 & $.509^{* *}$ & $.092 * *$ \\
\hline Neutral & .057 & -.009 & $.281^{*}$ & .061 & $.281^{*}$ & .058 & $.292^{*}$ & .069 & $.414^{* *}$ & $.133 * *$ & .135 & -.021 \\
\hline Analytical & -.060 & -.006 & .020 & -.017 & -.045 & -.006 & .058 & -.008 & .000 & -.062 & -.120 & -.014 \\
\hline Relational & .148 & .006 & .207 & .000 & $.279^{*}$ & .031 & .053 & -.017 & .043 & -.042 & $.410^{* *}$ & .033 \\
\hline Decisiveness & .094 & -.007 & .220 & .032 & .111 & -.010 & .019 & -.014 & .125 & $.057 *$ & $.322^{*}$ & .013 \\
\hline R Square $\left(\mathrm{R}^{2}\right)$ & \multicolumn{2}{|c|}{.063} & \multicolumn{2}{|c|}{.122} & \multicolumn{2}{|c|}{.131} & \multicolumn{2}{|c|}{.116} & \multicolumn{2}{|c|}{$.274 * *$} & \multicolumn{2}{|c|}{$.304 * *$} \\
\hline
\end{tabular}

Table 2. Continue.

\begin{tabular}{|c|c|c|c|c|c|c|c|c|c|c|}
\hline \multirow[t]{2}{*}{ Personality } & \multicolumn{2}{|c|}{ Persistence } & \multicolumn{2}{|c|}{ Vitality } & \multicolumn{2}{|c|}{ Charisma } & \multicolumn{2}{|c|}{ Integrity } & \multicolumn{2}{|c|}{ Overall } \\
\hline & $r$ & $\beta$ & $\mathrm{r}$ & $\beta$ & $\mathrm{r}$ & $\beta$ & $\mathrm{r}$ & $\beta$ & $\mathrm{r}$ & $\beta$ \\
\hline Openness & $.322^{*}$ & .034 & .140 & -.004 & $.265^{*}$ & .000 & $.322^{*}$ & .042 & $.367^{* *}$ & .254 \\
\hline Neutral & .160 & .000 & .162 & .066 & .152 & -.001 & .215 & -.006 & $.293^{*}$ & .349 \\
\hline Analytical & .011 & .013 & $-.290^{*}$ & $-.083^{*}$ & -.047 & .016 & .013 & .044 & -.066 & -.124 \\
\hline Relational & $.297^{*}$ & .029 & .239 & -.010 & $.445^{* *}$ & $.071 *$ & $.357^{* *}$ & $.062 *$ & $.355^{* *}$ & .162 \\
\hline Decisiveness & .251 & .008 & .092 & .035 & $.329^{*}$ & .029 & .110 & -.045 & .238 & .099 \\
\hline R Square $\left(\mathrm{R}^{2}\right)$ & \multicolumn{2}{|c|}{.137} & \multicolumn{2}{|c|}{.169} & \multicolumn{2}{|c|}{$.223 *$} & \multicolumn{2}{|c|}{$.205^{*}$} & \multicolumn{2}{|c|}{$.200 *$} \\
\hline
\end{tabular}

$* \mathrm{P}<0.05 * * \mathrm{P}<0.01$

Eleven standard multiple regressions were performed for all leadership qualities using five dimensions of personality scores as predictor variables (see Table 2). Results showed that the regression model was statistically significant for concern for others, $F(5,53)=4.01, \mathrm{p}<0.01$; self-confidence, $F(5,53)=4.63, \mathrm{p}<0.01$; charisma, $F(5,53)=3.04, \mathrm{p}<0.05$; integrity, $F(5,53)=2.73, \mathrm{p}<0.05$; and overall leadership qualities, $F(5,53)=2.66, \mathrm{p}<0.05$. Neutral personality score had the greatest beta weight and was the most significant predictor for the leadership quality, concern for others $(\beta$ $=.133, \mathrm{p}<0.01)$. The analysis showed that participants with higher Neutral personality scores were more likely to show concern for others. Open personality score was also a significant predictor of self-confidence $(\beta=.092, \mathrm{p}<0.01)$. Participants with more open personality traits were more likely to show confidence in their dealing with others. 
Relational personality score was a significant predictor for both charisma $(\beta=.071, p<0.05)$ and integrity $(\beta=.062, p$ $<0.05)$. Participants with strong relational personality traits were more likely to display their leadership qualities of charisma and integrity. Lastly, Analytical personality score was found to be a significant predictor for vitality that had a suppression effect $(\beta=-.083, \mathrm{p}<0.05)$. The correlation between Analytical personality score and vitality was negative $(\mathrm{r}=-.290, \mathrm{p}<0.05)$. The analysis showed that participants who were high in Analytical personality score would have a greater tendency to show low vitality.

\section{Discussion}

The finding indicates that student leaders who have been chosen by their members have very good leadership quality of integrity. These student leaders can be a very good future leader as integrity is considered as the most important quality of leadership [17]. Student leaders with high integrity will have the strength of character and honesty to lead their members and able to generate trust among their members who have chosen them. They will stand by their words and earn respect and loyalty from their followers and members [17]. The leadership quality that is ranked the lowest was charisma, indicating more training will be needed to boost this leadership quality among student leaders. Charisma is a special personal quality that causes others to show enthusiasm, admiration and loyalty [17]. In order to generate these kinds of reaction from followers, student leaders need to be trained in communication and relationship building skills, to enable them to be flexible in dealing with followers according to their characters and needs [24], to bond with followers and to stir their feelings to achieve higher goals [21].

The present findings provide support for personality dimensions as predictors of leadership qualities. Those with high scores in Neutral personality dimension were more likely to show concern for others. This result is expected because individuals with high Neutral personality dimension are good listeners, usually very supportive of others and always like to do things that are acceptable to others [24]. The chances for leaders with high Neutral personality dimension to show concern for others will be high and they probably consider the needs and interests of others first and they will be well-liked by followers as people-centered leaders.

Participants who scored high in Open personality dimension were more likely to have high level of self-confidence. This finding supports the idea that individuals with Openness personality profile tend to like new ideas and experiences and they like to be different and try new things [24]. Furthermore, they are risk takers who have enough self-confidence to face challenging tasks [17]. It is important for leaders to have openness to ideas and experience as the finding indicates that self-confidence was closely associated with openness and previous research has shown that openness to experience is important to ensure leadership effectiveness [26].

The findings also indicate that participants with high scores of Relational personality dimension were more likely to have high level of charisma and integrity. Individuals with Relational personality profile were found to enjoy talking with others, inspiring others and expressing feelings to others [24]. These characteristics of high Relational personality leaders will give added advantages to them in building human relationship because they are sociable and influential and they will have the charisma to generate interest and trust among followers [17, 23]. The finding seems to imply that leaders with high Relational personality dimension have the ability to talk, relate and express ideas or feelings, thus they are able to give impression to their followers that they have the strength of character and courage to stand by their words [17] and these characteristics were consistent correlate of leadership [23].

Lastly, participants who scored high in Analytical personality dimension were more likely to show low level of vitality. This finding is consistent with the idea that there may be a curvilinear relationship between analytic intelligence and leadership effectiveness [21]. When the leaders' analytic intelligence is too high, communication between leaders and followers may be affected since mental ability was found to influence the relationship between social skills and job performance [27]. Leaders with high Analytical personality scores may excel in giving detail instructions and structures, they may become too precise in setting procedures and goal because of their tendency toward precision and accuracy [24]. Therefore, too much of analysis can become a hindrance to vitality because more time may be needed to make decision. Enthusiasm may decrease if a decision takes too long to materialize.

By knowing the personality and leadership qualities that a person has, he or she can be helped to adapt according to the need of a situation, and thus becomes a more effective leader. A person does not emerge as a leader by simply having traits or qualities [13]. Since personality is associated with leadership quality, it is natural that a person with certain personality traits is more likely to display certain leadership qualities and engages in certain behaviors that are associated with effective leadership. By having those leadership qualities is not enough to be an effective leader, the leader will also need to be aware of his or her dominant personality trait. It is by trying to develop and improve on other qualities that are not shown readily and adapting them according to characteristics, goals and activities of followers that will make them effective leaders [13].

With the use of Leonard Personality Inventory, student leaders can be helped to become aware of their dominant personality dimension, their strengths and weaknesses. With this self-awareness about their personality, they will be able to adapt and work on their weaknesses, have the motivation to do more in their areas of strengths to enhance their leadership qualities, thus becoming a good leader. It is hoped that by developing and enhancing leadership qualities in them, these student leaders will bring the best out from others and develop the leadership qualities in others too in the process of their leadership, to help others to become leaders in their own way. The researcher would agree with Barry [12] that true 
leadership should not be based only on performance measurements, but an experience that touches our lives and lives of others at a deeper level. It is important to develop those qualities, to bring about changes in others, to become role models to others.

Although the empirical results indicate that personality traits can predict the leadership qualities displayed by student leaders to a certain extent, the interpretation of results need to take into consideration of some limitations to this study. The cross-sectional design used in this study make it not possible to determine the causal relationship between personality and leadership qualities. It will be good in future if a pretest and posttest study can be done to see whether leadership qualities can be enhanced through leadership training over a period of time. Another limitation to this study is that measurement of leadership qualities was done through self-report measure. There may be a possibility that participants give socially acceptable answers. The leadership qualities displayed in the research results may not reflect the actual leadership qualities that those student leaders have. It will be good if evaluation of those leadership qualities was also done by followers or peers. The study was also limited with the use of personality with its five dimensions of personality scores in the analyses as predictor variables for leadership qualities among student leaders. The finding indicates that a significant proportion of variance is due to factors other than personality. Future studies may include other variables such as leaders' behaviors, leadership effectiveness, gender and age in predicting the leadership qualities among students.

In conclusion, the student leaders who were chosen by their peers to lead societies and clubs do have high level of integrity to lead. To a certain extent, the personality of leaders influences the leadership qualities that they display readily. These emerging leaders need further leadership training to enhance their leadership qualities and make them a better leader in the future.

\section{References}

[1] Shakir, R. (2009). Soft skills at the Malaysian institutes of higher learning. Asia Pacific Education Review, 10, 309 - 315.

[2] Shertzer, J., Wall, V., Frandsen, A., Guo, Y., Whalen, D. F., \& Shelley, M. C. (2005). Four dimensions of student leadership: What predicts student' attitudes toward leadership development? College Student Affairs Journal, 25, 85 - 108.

[3] Yang, C. (2014). Does Ethical Leadership Lead to Happy Workers? A Study on the impact of ethical leadership, subjective well-being, and life happiness in the Chinese culture Journal of Business Ethics, 123, 513-525.

[4] Pierro, A., Raven, B. H, Amato, C., \& Belanger, J. J. (2013). Bases of social power, leadership styles, and organizational commitment. International Journal of Psychology, 18, $1122-$ 1134.

[5] Hochwarter, W. A., Witt, L. A., Treadway, D. C., \& Ferris, G. R. (2006). The interaction of social skill and organizational support on job performance. Journal of Applied Psychology,
$91(2), 482-489$.

[6] Curtis, E. A., Vries, J. D., \& Sheerin, F. K. (2011). Developing leadership in nursing: Exploring core factors. British Journal of Nursing, 20, $6-9$.

[7] Zilembo, M., \& Monterosso, L. (2004). Nursing students perceptions of desirable leadership qualities in nurse preceptors: A descriptive survey. Contemporary Nurse, 27, $194-206$.

[8] Heller, B. R., Drenkard, K., Esposito-Herr, M.B., Romano, C., Tom, S., \& Valentine, N. (2004). Educating nurses for leadership roles. Journal of Continuing Education in Nursing, $35,203-210$.

[9] Ozgen, S., Sanchez-Galofre, O., Alabart, J. R., Medir, M.m \& Giralt, F. (2013). Assessment of engineering students' leadership competencies. Leadership and Management in Engineering, $13,65-75$.

[10] White, D. A. (2004). Defining student leadership: A literature review. The Journal of Youth Ministry, 2, $65-73$.

[11] Unsar, A. S., \& Karalar, S. (2013). The effect of personality traits on leadership behaviors: A research on the students of business administration department. Economic Review Journal of Economics and Business, 6, 45 - 56.

[12] Barry, T. J. (2002). Character \& Leadership: A Sacred Trust. Sintok: Universiti Utara Malaysia Press.

[13] Pierce, J. L., \& Newstrom, J. W. (2006). Leaders \& the Leadership Process: Readings, Self-Assessments, \& Applications (4th ed.). Boston: McGraw-Hill.

[14] Kirkpatrick, S. A. \& Locke, E. A. (1991). Leadership: Do traits matter? Academy of Management Executive, 5, 48 - 60.

[15] Lord, R. G., DeVader, C. L., \& Alliger, G. M. (1986). A meta-analysis of the relation between personality traits and leadership perceptions: An application of validity generalization procedures. Journal of Applied Psychology, 71, $402-410$.

[16] Hoffman, B. J., Woehr, D. J., Maldagen-Youngjohn, R., \& Lyons, B. D. (2011). Great man or great myth? A quantitative review of the relationship between individual differences and leader effectiveness. Journal of Occupational and Organizational Psychology, 84, $347-381$.

[17] Manning, G., \& Curtis, K. (2007). The Art of Leadership (2nd ed.). Boston: McGraw-Hill.

[18] Hogan, R., Curphy, G. J. \& Hogan, J. (1994). What we know about leadership: Effectiveness and personality. American Psychologist, 49, $493-504$.

[19] Friedman, H. S., \& Schustack, M. W. (2012). Personality: Classic Theories and Modern Research (5th ed.). Boston: Pearson.

[20] Feist, J., \& Feist, G. J. (2009). Theories of Personality (7th ed.). Boston: McGraw Hill.

[21] Hughes, R. L., Ginnett, R. C., \& Curphy, G. J. (2006). Leadership: Enhancing the Lessons of Experience (5th ed.). Boston: McGraw Hill.

[22] Cloninger, S. (2013). Theories of Personality: Understanding Persons Personality. Boston: Pearson. 
[23] Judge, T. A.. Bono, J. E., Ilies, R., \& Gerhardt, M.W. (2002). Personality and leadership: A qualitative and quantitative review. Journal of Applied Psychology, 87, 765 - 780.

[24] Yong, L. (2007). Emotional Excellence in the Workplace: Leonard Personality Inventory (LPI) Personality Profiling. Kuala Lumpur: Leonard Personality Incorporated Sdn Bhd.

[25] Yong, L. M. S. (2003). Norms \& Technical Manual: The Leonard Personality Inventory (LPI). Kuala Lumpur: Leonard Personality Incorporated Sdn Bhd.
[26] Hogan, J. and Holland, B. (2003). Using theory to evaluate personality and job performance relations: A socioanalytic perspective. Journal of Applied Psychology, 88(1), 100 - 112.

[27] Ferris, G. R., Witt, L. A., \& Hochwarter, W. A. (2001). Interaction of social skill and general mental ability on job performance and salary. Journal of Applied Psychology, 86 (6), $1075-1082$. 